I still like linen. Peach colored linen. I think of tanning my legs. I feel the word prayer in my mind. Just the word. A smooth river stone. I'm accomplishing the miles to San Francisco for the thousandth time, add them to my vita. I'm better off than Mona's mother with her hair in curl papers thirty years, waiting for the occasion. I have occasion. Press on. Oh soul of mud. Half of what sacrifice ransoms us?

\title{
When Rain Pulls the Wind off the Arno at Night
}

Thunder booms through the house like waves boom at sea when the mast is a twig, booms like the avalanche that took Vera at Annapurna, riveting her blue jacket to a crevice of ice, booms like my father's voice warning me not to bathe when it thunders, lightning waits to strike girls with pearly toes and sunburned shoulders, and will split the room, lift the porcelain tub and my white hide to the sky; a flash divides the night in my closed eyes, the sky a bare dendritic slide of winter birch what long roots dangle. I hold my breath. But isn't it good, the gigantic storm? Waking to the flood of terror they felt by fires in the caves? I find a match but the candle displaces the dark only half way up the wall. I ricochet homeheat lightning in the South. I used to lie on the ground letting rain soak through me, feeling each bright burst of forked silver.

Quick wind parts the bedroom shutters, 
and strands and loops of rain pool on desk and floor.

Rain flaying the grapes, rain filling the mouths of the dead so they stop their endless chatter. Was I dreaming of my mother rinsing my tangle of hair with a bowl of rainwater? How do I lie here seven thousand years from home? How are the mares? Where are the six dumb guinea hens? All ride the earth lightly, our limbs a brief inflorescence. What did that refrain mean, "cleft for me," rising perpendicular from the white board church in Georgia? Bolts spear the ground, crack along my backbone. The road in is a river. All fuses are blown. Shutters could twirl over the fields, bolts peel off my body, leave me foreign, clean stripped, electric. 